\title{
Correction to: Insulin glargine/lixisenatide in type 2 diabetes: a profile of its use
}

\author{
Emma Deeks ${ }^{1}$
}

Published online: 14 October 2019

(c) Springer Nature 2019

\section{Correction to: Drugs \& Therapy Perspectives (2019) 35:470-480 https://doi.org/10.1007/s40267-019-00670-4}

The article Insulin glargine/lixisenatide in type 2 diabetes: a profile of its use, written by Emma Deeks, was originally published Online First without Open Access. After publication in volume 35 , issue 10 , pages $470-480$, Sanofi requested that the article be Open Choice to make the article an open access publication. Post-publication open access was funded by Sanofi. Therefore, the copyright of the article has been changed to (C) Springer Nature 2019 and the article is forthwith distributed under the terms of the Creative Commons Attribution-NonCommercial 4.0 International License (http://creativecommons.org/licenses/by-nc/4.0/), which permits any noncommercial use, duplication, adaptation, distribution and reproduction in any medium or format, as long as you give appropriate credit original author(s) and the source, provide a link to the Creative Commons licence and indicate if changes were made.

The original article has been corrected.

Open Access This article is distributed under the terms of the Creative Commons Attribution-NonCommercial 4.0 International License (http://creativecommons.org/licenses/by-nc/4.0/), which permits any noncommercial use, distribution, and reproduction in any medium, provided you give appropriate credit to the original author(s) and the source, provide a link to the Creative Commons license, and indicate if changes were made.
Emma Deeks

demail@ springer.com

1 Springer Nature, Private Bag 65901, Mairangi Bay, Auckland 0754, New Zealand 